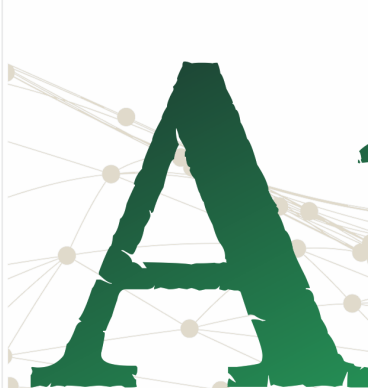

ISSN n² 2526-8031

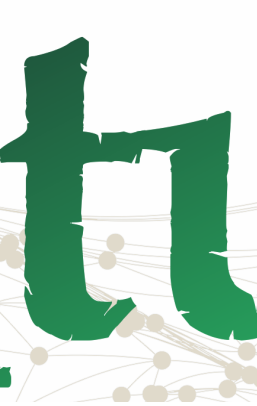

tur

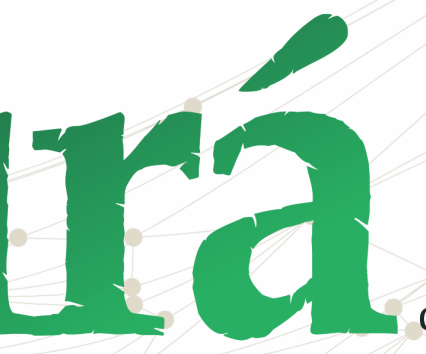

Pan-Amazônica de Comunicação

\title{
OS JORNAIS IMPRESSOS DE RORAIMA E AS TRANSFORMAÇÕES NA ATIVIDADE POLÍTICA ESTADUAL (1914-1989) ${ }^{1}$
}

Roraima's print newspapers and the transformations in state political activity (1914-1989)

Los periódicos impresos de Roraima y las transformaciones en la actividad política estatal (1914-1989)

\section{Luís Francisco Munaro² Cyneida Menezes Correia ${ }^{3}$}

\section{RESUMO}

O objetivo deste trabalho é analisar trajetória dos jornais impressos de Roraima no recorte que vai da fundação do primeiro jornal local até a transformação de Roraima em Estado, a partir da seguinte periodização: jornalismo impresso durante o pertencimento de Roraima ao Estado do Amazonas (1914-1942), durante o período em que Roraima se transformou em território federal (1943-1979) e fase de consolidação da atividade impressa (1981-1989). Ele fará isso através da recuperação de acervos documentais e identificação de jornais e atores importantes na construção de uma cultura letrada regional em paralelo com a transformação política do Estado. Ao fazer semelhante levantamento, será possível reforçar hipóteses sobre porque são tão conflituosas as relações entre o estamento político regional e os canais impressos.

\footnotetext{
${ }^{1}$ Um esboço deste artigo foi apresentado no DT 1 - Jornalismo do XVIII Congresso de Ciências da Comunicação na Região Norte, realizado de 24 a 26 de junho de 2019.

2 Professor adjunto do Curso de Comunicação Social da Universidade Federal de Roraima (UFRR). Graduado em História e em Jornalismo pela Universidade Estadual do Centro-Oeste (UNICENTRO), mestre em Jornalismo pela Universidade Federal de Santa Catarina (UFSC) e Doutor em História pela Universidade Federal Fluminense (UFF). E-mail: luismunaro@yahoo.com.br.

3 Jornalista em Roraima. Graduada em Comunicação Social e mestranda em Comunicação pela Universidade Federal de Roraima. E-mail: cyneida@gmail.com.
} 


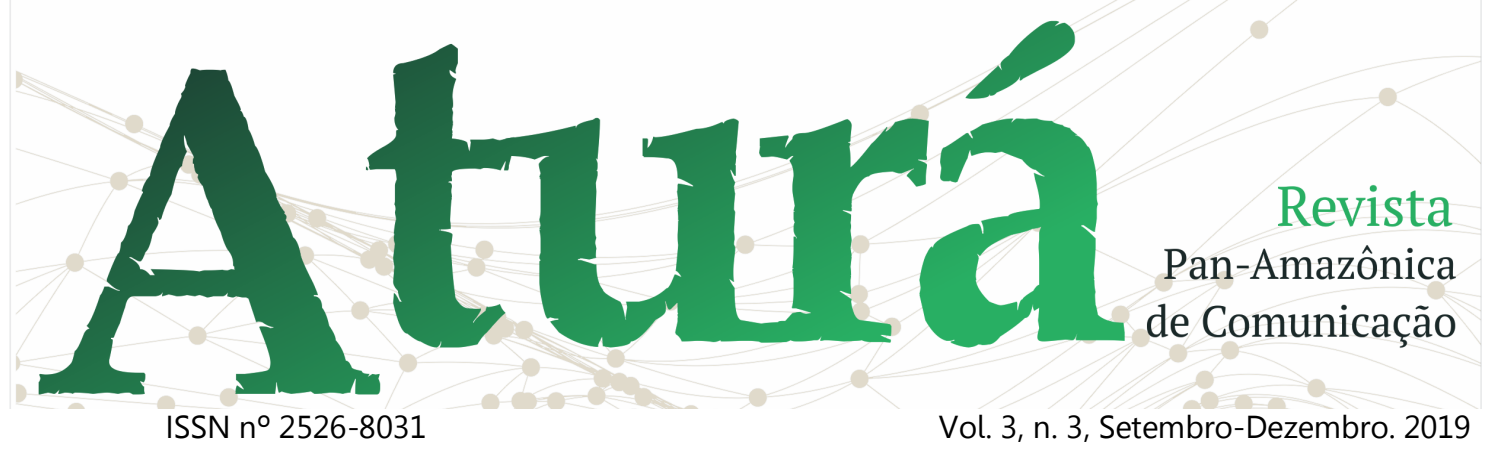

PALAVRAS-CHAVE: História da imprensa; Roraima; História política; Mídia impressa; Boa Vista.

\begin{abstract}
The objective of this paper is to analyze the trajectory of Roraima's printed newspapers in the cut that goes from the foundation of the first local newspaper to the transformation of Roraima into a state, from the following periodization: printed journalism during the Roraima's belonging to the State of Amazonas ( 1914-1942), during the period in which Roraima became federal territory (1943-1979) and the consolidation phase of printed activity (1981-1989). It will do this by recovering documentary collections and identifying newspapers and key players in building a regional literate culture in parallel with the political transformation of the state. By making such a survey, it will be possible to reinforce hypotheses as to why the relations between the regional political settlement and the print channels are so conflicting.
\end{abstract}

KEYWORDS: History of the press; Roraima; Political history; Print; Boa Vista.

\title{
RESUMEN
}

El objetivo de este trabajo es analizar la trayectoria de los periódicos impresos de Roraima en el corte que va desde la fundación del primer periódico local hasta la transformación de Roraima en un estado, desde la siguiente periodización: periodismo impreso durante la pertenencia de Roraima al Estado de Amazonas ( 1914-1942), durante el período en que Roraima se convirtió en territorio federal (1943-1979) y la fase de consolidación de la actividad impresa (1981-1989). Lo hará recuperando colecciones documentales e identificando periódicos y actores clave en la construcción de una cultura regional alfabetizada en paralelo con la transformación política del estado. Al realizar una encuesta de este tipo, será posible reforzar las hipótesis de por qué las relaciones entre el acuerdo político regional y los canales impresos son tan conflictivas.

PALABRAS CLAVE: Historia de la prensa; Roraima Historia política; Medios impresos; Boa Vista.

Recebido em: 12.06.2019. Aceito em: 09.08.2019. Publicado em: 01.09.2019. 


\section{A \\ ISSN n 2526-8031 \\ Vol. 3, n. 3, Setembro-Dezembro. 2019}

\section{Introdução}

Este artigo tem como objetivo central analisar a trajetória dos jornais impressos de Roraima no recorte que vai da fundação do primeiro jornal impresso local (1914) até a transformação de Roraima em Estado em 1989. A história da mídia, neste trabalho, terá como ponto de partida o surgimento, em 1914, do primeiro jornal impresso, quando Boa Vista se chamava Freguesia de Nossa Senhora do Carmo do Rio Branco e pertencia ao município de Barcelos, no Estado do Amazonas. A partir desta baliza inicial, construiu-se a seguinte periodização: jornalismo impresso em seus primeiros passos, durante o pertencimento de Roraima ao Estado do Amazonas na condição de freguesia (1914-1942), jornalismo impresso durante o período em que Roraima se transformou em território federal (1943-1979) e fase de consolidação da atividade impressa (1981-1989).

Este trabalho faz parte de um estudo mais abrangente que parte da seguinte pergunta: em mais de um século de existência, que transformações significativas podem ser percebidas na imprensa escrita de Roraima e como a mídia impressa ajudou a moldar e foi moldada pelas atividades políticas regionais? Ele fará isso através da recuperação de acervos documentais e identificação de jornais e atores importantes na construção da cultura letrada regional. Ao fazer semelhante levantamento sobre o histórico da imprensa roraimense, será possível reforçar hipóteses sobre porque são tão conflituosas as relações entre o estamento político regional e os canais impressos.

O programa de estudos, neste artigo, consiste na catalogação e descrição dos jornais existentes em Roraima no período destacado, sempre que possível apontando a sua inter-relação com a esfera do político a partir de conceitos apresentados por René Rémond et all (2003). Segundo esta proposta, - político se estabelece como "uma modalidade da prática social, estabelecendo relações com os demais aspectos da vida coletiva", dentro do qual disputam espaço atores motivados por interesses culturais, econômicos, sociais etc (2003, p. 35). No que 


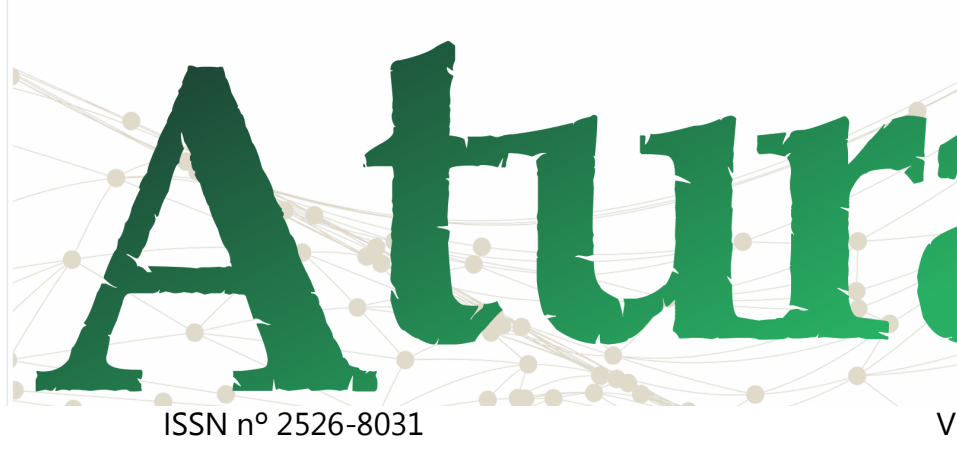

Vol. 3, n. 3, Setembro-Dezembro. 2019 concerne ao jornal, consiste num meio de fundamental importância para a construção da opinião pública, sendo necessário considerar que os jornais não são apenas o "meio de expressão de espíritos independentes, mas também, e com muito mais frequência, de grupos de pressão diversos, políticos ou financeiros" (Ibid, p. 196).

\section{Do manuscrito ao impresso}

Antes mesmo da produção de impressos, no período supracitado, há registros de manuscritos efêmeros como $O$ Caniço (1905), Tacutú (1907), O Graveto, O Sabiá, O Bem-te-vi (SANTOS, 1990). Os manuscritos foram um recurso local importante para compensar a ausência de máquinas tipográficas nos interiores do Estado do Amazonas. Ainda que com o boom do comércio da borracha (1880-1910) tenha havido notável expansão dos impressos, a vila do Rio Branco não possuiu nenhuma tecnologia tipográfica até 1914. O Caniço, primeiro destes jornais, foi elaborado com letras desenhadas sobre quatro folhas de papel almaço, publicado a cada quinze dias numa tiragem de 50 exemplares. Além de apurarem as novidades, os redatores eram também jornaleiros e se encarregavam de levar os exemplares de canoa para distribuírem nas casas dos moradores. O periódico circulou por dois anos, até 1907, embora não tenha conseguido manter sempre a periodicidade (JUPIRA, 2003). Do ponto de vista do conteúdo, O Caniço tanto elogiava os políticos considerados amigos quanto criticava os adversários. Na sua edição de 15 de julho de 1907, o jornal já se apresentava como um prócere do Coronel Bento Brasil, constituindo um caso bastante curioso de proselitismo jornalístico manuscrito: "O município desde que teve a felicidade de ter como o chefe o Sr. Cel. Bento Brasil vai tomando proporções animadoras. Tendo os impostos pagos aqui, já se percebe a circulação de dinheiro e todos os empregados públicos satisfeitíssimos!" (Ibid). O manuscrito Caniço representa uma versão bastante embrionária da imprensa do coronel bacharel que vai ganhar várias partes da bacia hidrográfica amazônica (MUNARO, 2018). Ele deu início ao processo de formação de uma esfera pública local através da busca por 


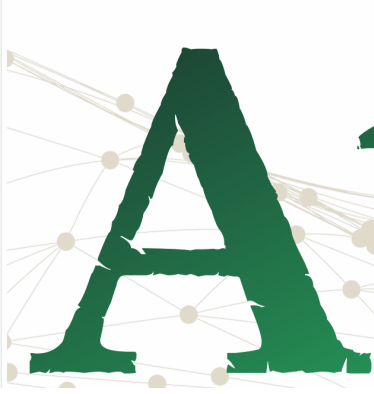

ISSN n $2526-8031$

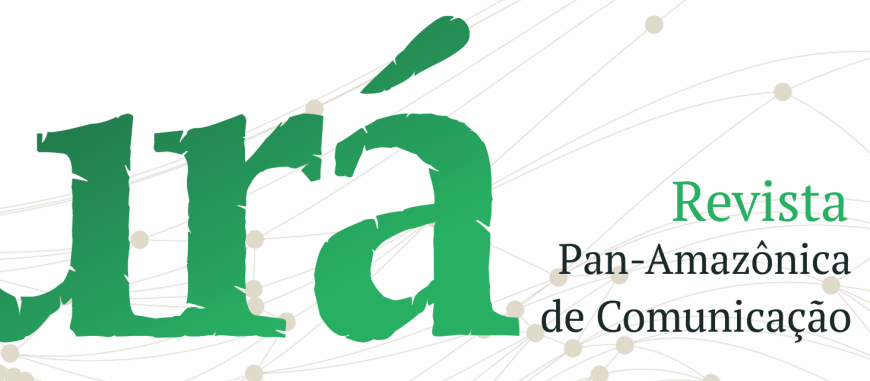

Vol. 3, n. 3, Setembro-Dezembro. 2019 estender a influência do coronel Bento Brasil sobre a dinâmica da vila. Não é de menor importância que neste ponto tão distante da Amazônia as folhas periódicas já fossem vistas como importantes elementos da manutenção de um círculo de poder local, capaz de evidenciar os aspectos positivos de um político (pride gossip) e afastar os concorrentes via fofoca negativa (blame gossip). O estilo gráfico imortalizado nas marcas textuais revela outras características peculiares dando novas pistas sobre os processos produtivos. A letra regular $\mathrm{e}$ cuidadosamente desenhada do número $10 \mathrm{de}$ o Caniço e, o mais importante, sem qualquer rasura, o que era incomum nos manuscritos, indica que aquele número foi recopiado, retirando-se dele as possíveis incorreções.

O segundo jornal manuscrito, intitulado Tacutu, surgido em março de 1907, possuía periodicidade mensal. Não foram deixados dados de seus editores e nem de sua linha editorial disponíveis em publicações consultadas e seu fechamento aconteceu no intervalo de trinta dias, tendo ficado registro de apenas duas edições. Sua primeira edição saiu em março de 1907 e em abril do mesmo ano circulou o seu último exemplar (JUPIRA, 2003). Ainda há relatos de outros dois manuscritos: $O$ Carvão dirigido por Artur Virgilio do Carmo Ribeiro e Bem-te-vi, dirigido por Manoel Afonso dos Santana. Estes dois últimos jornais retratavam 0 cotidiano das famílias do Rio Branco por meio da sátira, ainda circunscritos ao espaço de uma vila com menos de mil habitantes (MENEZES, 2006).

Algumas das informações que ainda existem e podem ser verificadas sobre estes manuscritos foram divulgadas por meio de pequenos recortes ou páginas descontínuas que se encontram no arquivo público do Palácio da Cultura em Roraima. De acordo com Rodrigues (1996), desde o surgimento da imprensa manuscrita no Território Federal do Rio Branco, quando Roraima ainda era um município e pertencia ao Estado do Amazonas, tem-se notícias do envolvimento de jornais e de jornalistas nas políticas partidárias locais, dentro do esquema político que na República Velha se tornou conhecido como coronelismo. Neste esquema, a vida municipal tinha como principal autoridade política, social e militar um indivíduo 


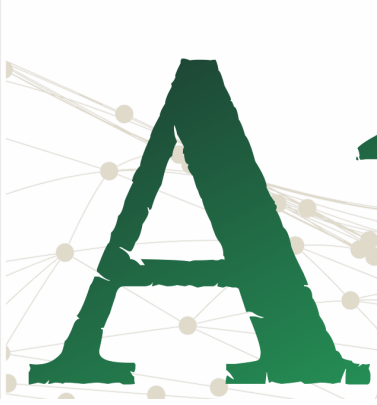

ISSN n² 2526-8031

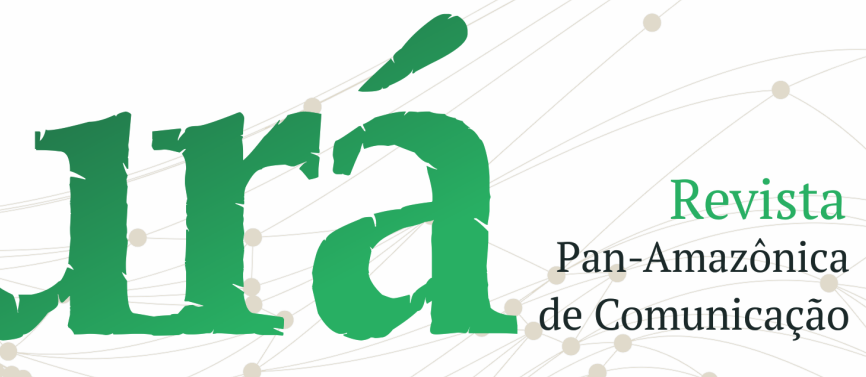

Vol. 3, n. 3, Setembro-Dezembro. 2019 identificado como coronel, responsável tanto pela pacificação local quanto pela conquista de votos no cenário estadual (LEAL, 2012). Assim, Coronel Bento Brasil foi um dos indivíduos mais poderosos neste processo de estabelecimento político da vila e, não menos importante, foi elogiado nos jornais.

A consolidação do jornalismo em Roraima aconteceu a partir da dinamização da vida social na vila com a expansão do cultivo de gado voltado para o fornecimento de carne para a cidade de Manaus. Na década de 1910, ainda que tenha havido o recrudescimento comercial amazônico, houve o registro dos jornais impressos O Rio Branco e Jornal do Rio Branco. Coube ao Rio Branco - Jornal Independente, em 1914, propriedade de Diomedes P. Souto Maior e Alfredo Carmo Ribeiro, o título de primeiro jornal impresso de Boa Vista. Na condição de militar e professor migrado do Nordeste, Diomedes envolveu-se em debates políticos que tangiam à transformação do Brasil em República, recebendo informações de outros cantos do país através da Repartição Geral dos Telégrafos (MUNARO, 2017). Sob o mesmo nome de Rio Branco, o jornal reaparecerá nos registros históricos em 1918, buscando incentivar uma ocupação ordeira da região. Num de seus números, menciona a viagem do "abastado" Coronel Bento Brasil a Manaus, externando "afetuosas saudações". Nesta altura do campeonato, Bento Brasil cumpria um de seus quatro mandatos como Deputado Estadual no Amazonas. Também era mencionada a sua Casa Comercial, responsável por "grande sortimento de estivas, fazendas, miudezas e ferragens". O registro deste nome, bem como de outros coronéis, permite pensar a articulação local do coronelismo e seu grau de utilização dos jornais como instrumento político, ainda que em Roraima isto aconteça de forma apenas rudimentar dada a pequena dimensão da vila e alto grau de analfabetismo.

O Jornal do Rio Branco, que apareceu entre os dois primeiros registros citados, nos anos de 1916 e 1917, tinha como subtítulo "Orgam dos Interesses dos moradores de Boa Vista", e "circulou mensalmente impresso nas oficinas dos padres Beneditinos" (CRUZ, 1998, p 23). Este jornal marca a participação missionária no fomento de uma cultura letrada no Rio Branco, participação essa que 


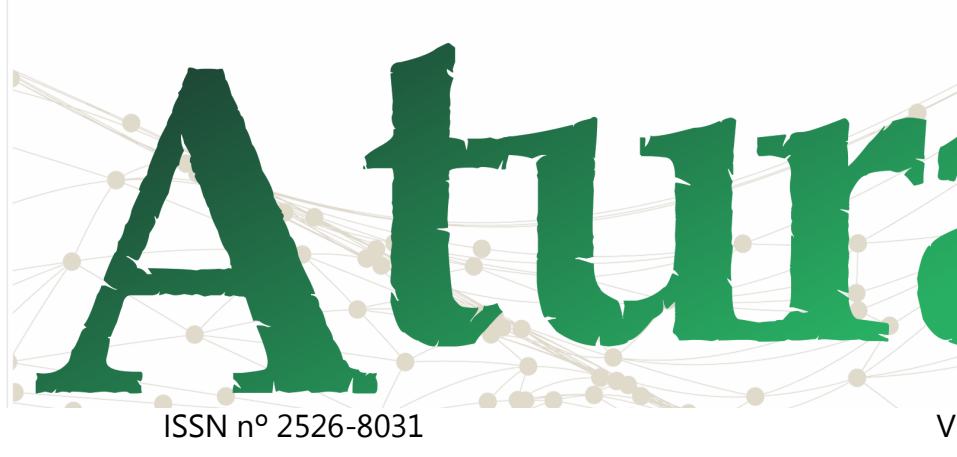

Vol. 3, n. 3, Setembro-Dezembro. 2019

se deu desde a confecção do seu editorial até a impressão. O jornal cumpriu o papel ambíguo de tentar fomentar uma cultura cristã na vila de Boa Vista e, ao mesmo tempo, amortecer as pressões dos fazendeiros sobre as comunidades indígenas. Neste período, as disputas políticas entre beneditinos $\mathrm{e}$ autoridades locais, que foram ferozes na primeira década do século XIX, já estavam relativamente pacificadas. Os monges aprenderam a conviver com os poderes estabelecidos e, ao mesmo tempo, propunham levar a tarefa evengelizadora até as comunidades indígenas mais distantes. Para os religiosos do jornal, a distância dos centros de poder decisório dificultava em enorme grau a tarefa civilizatória que, neste momento, já era percebida como uma inelutável comunhão de forças políticas vinculadas ao trabalho e forças missionárias vinculadas a padrões de moralidade cristãos. Esta dinâmica de forças que opõe o coronel ao monge se fracionou a partir da década de 1930, quando o golpe getulista promoveu um rearranjo de forças em nível nacional e local criando, inclusive, o Território Federal de
Roraima em 1943 sob intervenção federal direta.

De 1919 até 1945, na vila do Rio Branco, transformada em cidade de Boa Vista, não circularam periódicos em virtude de questões políticas, sociais e financeiras. Bem como, por outro lado, pela existência de grandes jornais em Manaus que supriam uma importante demanda local, como o Jornal do Comércio. Em torno de 1920, a população local ainda girava em torno de 1000 habitantes e pequena porcentagem de letrados tornava difícil o consumo e a circulação de impressos.

\section{Os jornais no Território Federal de Roraima}

Por obra de Getúlio Vargas, em 1943 Roraima foi elevada à condição de Território Federal, administrado por uma interventoria designada pelo poder central que primeiro coube ao militar Ene Garcez. De acordo com Shirley Rodrigues (1996), em 1945 foi editado o primeiro número do Boletim Oficial do Governo do Território Federal do Rio Branco pela empresa de propriedades de Das Medeiros e Cia, Misael Guerreiro e da Prelazia 


\section{A \\ ISSN n $2526-8031$}

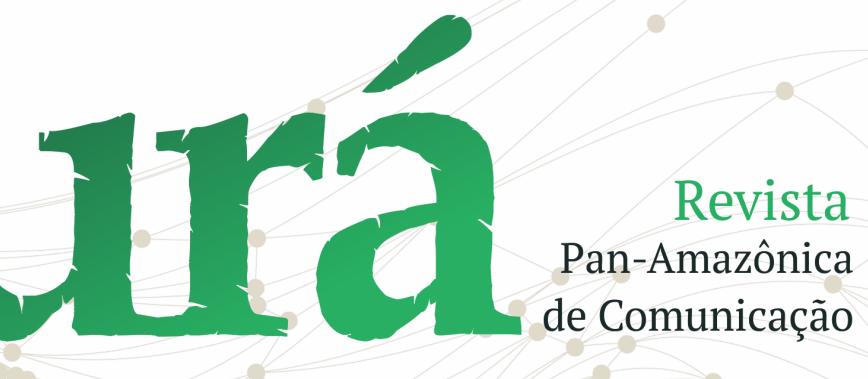

Vol. 3, n. 3, Setembro-Dezembro. 2019 do Rio Branco. Dois anos depois, em 1947, ainda de acordo com Rodrigues (Ibid.), foi criado O Boa Vista, primeiro jornal do governo do Território Federal do Rio Branco, caracterizado como noticiário geral (favorável ao executivo) com uma tiragem de trezentos exemplares e circulação semanal que durou até 1958. Foi característico deste impresso noticiar os acontecimentos vinculados ao governo do Estado, ecoando, de forma positiva, as suas ações (JUPIRA, 2003). Depois de sua criação, tornou-se uma publicação muito irregular até a sua última edição. Ele voltou a circular apenas em 1973, com o título reduzido para Boa Vista. O Governador da época, Coronel Hélio Campos (1970-1974), foi quem resolveu fazer renascer o jornal Boa Vista, com o título Jornal Boa Vista, desta vez através do que havia de mais moderno na época, uma offset e outros equipamentos necessários para a produção do impresso: "A equipe encarregada de produzir a edição não teve criatividade para fazer os títulos em tamanho grande e imprimiu o jornal com os títulos feitos em letras manuscritas" (CRUZ, 1998, p. 20).
Com a falta de equipamentos avançados no parque gráfico, o trabalho era muito limitado e, por essa razão, a equipe encarregada pela impressão não tinha condições de produzir o título do jornal em tamanho maior que o texto normal. Isto desagradou o governador Hélio Campos, que determinou que toda a edição fosse queimada. Em 1974, sob a direção de Laucides Oliveira, o jornal circulou com uma nova diagramação e fotografias consideradas mais apropriadas (SILVA, 2014). O jornal teve os seus últimos exemplares impressos no ano de 1983 quando deixou definitivamente de circular (JUPIRA, 2003). O caso deste jornal ilustra todo o esquema de produção impressa ao longo do período do território federal: com imenso poder político, o governador matinha os instrumentos simbólicos de poder sob sua interferência direta, podendo mesmo queimar exemplares que the pareciam desfavoráveis.

Ao longo desse processo, em 1951, nasceu $O$ Átomo, o primeiro jornal construído para fazer oposição ao governo do território, apesar de que não tenha nunca declarado abertamente esta posição. Tinha como 


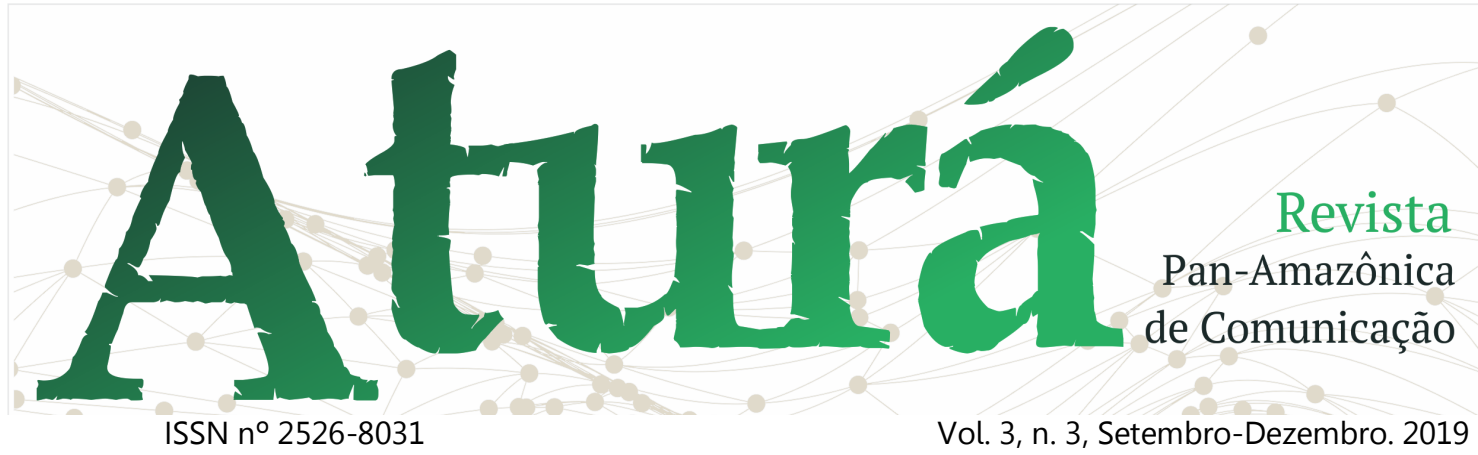

proprietário o tenente José Estevam Guimarães que, de forma ambígua, se beneficiava de alguns favores do governo (SILVA, 2014). Há relatos de que quando havia a presença de informações que desagradavam os governantes, estes mandavam recolher todos os jornais como forma de evitar que a população tivesse contato com notícias incômodas. Portanto, os governadores de território tinham controle bastante estrito sobre a circulação de informações nos impressos. O Átomo foi mais tarde comprado por membros do governo do território em 1957:

Para isso o poder econômico era fundamental, pois quando o jornal não agradava aos palacianos, a solução encontrada pelo Executivo era comprar o jornal como garantia dos fins das críticas ao poder. Foi exatamente isso que aconteceu

com o Átomo e outros pequenos jornais. No período territorial foi comum que os jornais, com raríssimas exceções, nascessem sob a égide política e terem seu crepúsculo determinado pelos mesmos fins, isto é, as questões políticas (JUPIRA, 2003, p. 120).

A maioria das suas matérias presentes neste periódico era referente à política nacional e local, fazendo severas críticas a algumas figuras do cenário político, principalmente ao então deputado federal Félix Valois de Araújo (1946-1947). Destarte, O Átomo era o jornal mais vendido da época e se apresentava como rival do jornal $\mathrm{O} B \mathrm{BO}$ Vista que, apesar de maior qualidade física, era recebido com descrença pela população por conta do vínculo direto com a governança do território (MENEZES, 2008). O jornal publicou a sua última edição em 1959. 


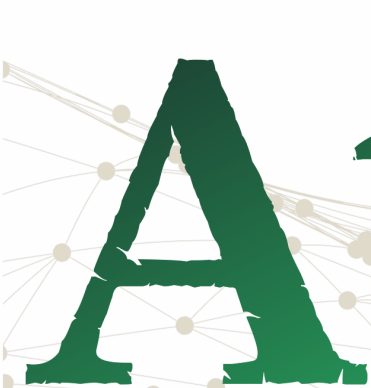

ISSN n² 2526-8031

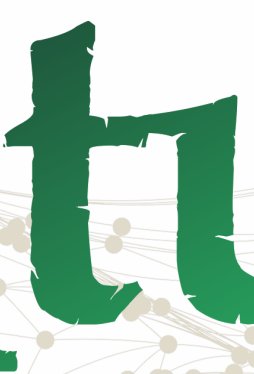

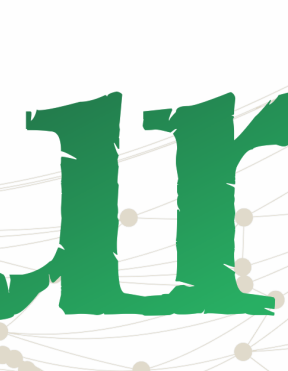

ra

Vol. 3, n. 3, Setembro-Dezembro. 2019

Figura 1 - Capa do jornal "O Átomo", edição n 153 do dia 28 de agosto de 1954, onde relatava a posse de Café Filho e o suicídio de Getúlio Vargas

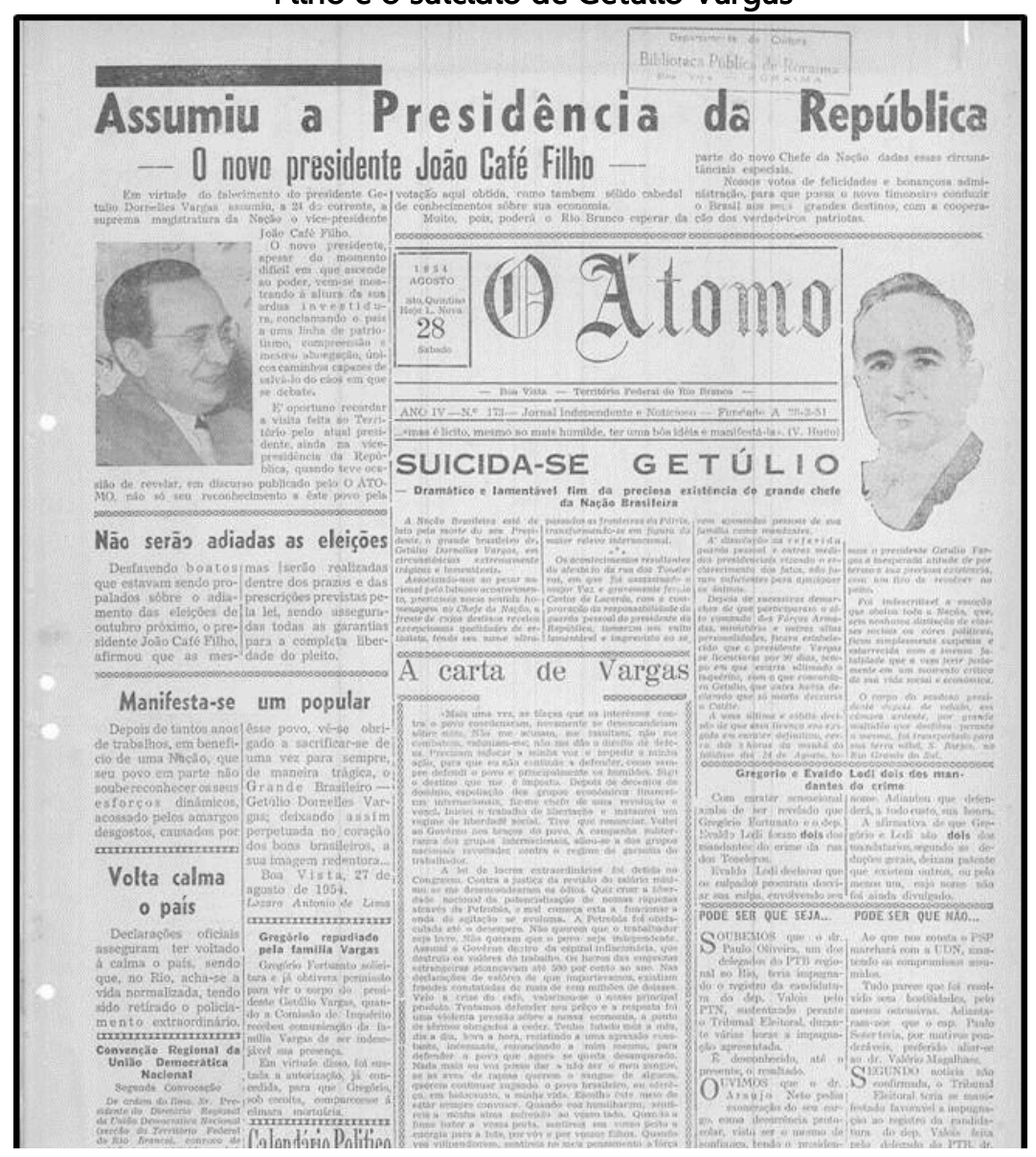

Fonte: Aragão, 2015 / Acervo digital do Intercom

Em 1951, surgiu jornal intitulado 0 Tenente Guimarães, de propriedade de José Estevão Guimarães, editado em Manaus até 1954. Este jornal combatia as notícias publicadas no Átomo, ou seja, funcionou como outro jornal de situação. Logo depois, em 1953, surgiu um segundo jornal de oposição no território, $O$ Combate, jornal mensal de propriedade de Afonso Rezende. Este jornal foi editado em Manaus e também teve vida curta no território, parando de ser 


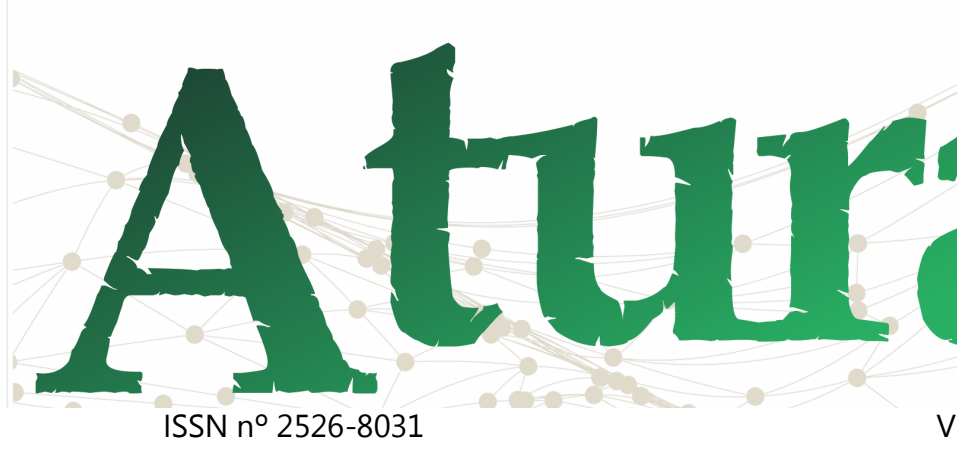

Vol. 3, n. 3, Setembro-Dezembro. 2019

impresso em 1954 (MADEIRA, 2003). Até aqui se observa, portanto, a dificuldade de estabelecer máquinas tipográficas no território, sendo os jornais predominantemente impressos em Manaus e sendo deslocados até Boa Vista através do Rio Branco.

Em 1960, outro jornal que surgiu e desapareceu repentinamente a partir da atividade de uma figura política de destaque na região foi o jornal amazonense $A$ Tarde, que teve $\mathrm{o}$ papel de dar sustentação à candidatura de Gilberto Mestrinho a Deputado Federal pelo Território do Rio Branco (o jornal fechou as suas portas tão logo terminaram as eleições de 1962). Como lembra Getúlio Cruz, "com a revolução militar de 1964, Gilberto Mestrinho teve o mandato cassado e o jornal foi extinto" (1998, p. 24).

O mesmo autor reforça que, em 1960, Laucides Oliveira, Raimundo Wanderley e Sebastião Diniz publicaram no território o tabloide Folha Esportiva que circulou cerca de um ano sem nenhuma notícia explicitamente política. $O$ jornal era impresso e rodado na mesma imprensa administrada por Antônio Rodrigues, onde também era impresso 0 jornal $A$ Tribuna do Norte que apareceu no cenário boa-vistense em 1967 ligado ao governador Hélio Campos. Era editado e impresso semanalmente no formato tabloide na imprensa oficial, tendo como diretora Ana Cecília M. Pereira e diretor de redação Antônio R. Pereira, deixando de circular em 1970.

O ex-governador do Amazonas, Gilberto Mestrinho, candidatou-se neste ano a uma vaga para deputado federal pelo Território Federal do Rio Branco e, junto com o empresário Carlos Gonçalves, inaugurou em 1987 O Diário do Povo, criado com o objetivo dar apoio à sua campanha eleitoral. O empreendimento do jornal diário sem uma estrutura de suporte $e$ as constantes divergências internas do grupo resultaram em um desastre e em menos de um mês de circulação o jornal fechou as portas (SOARES, 1998)

Há um silêncio na produção jornalística no Território Federal de Roraima no período de 1962 a 1973. Além da implantação da Ditadura Civil Militar, que tornou bastante limitada a possibilidade de circulação de impressos políticos num território 


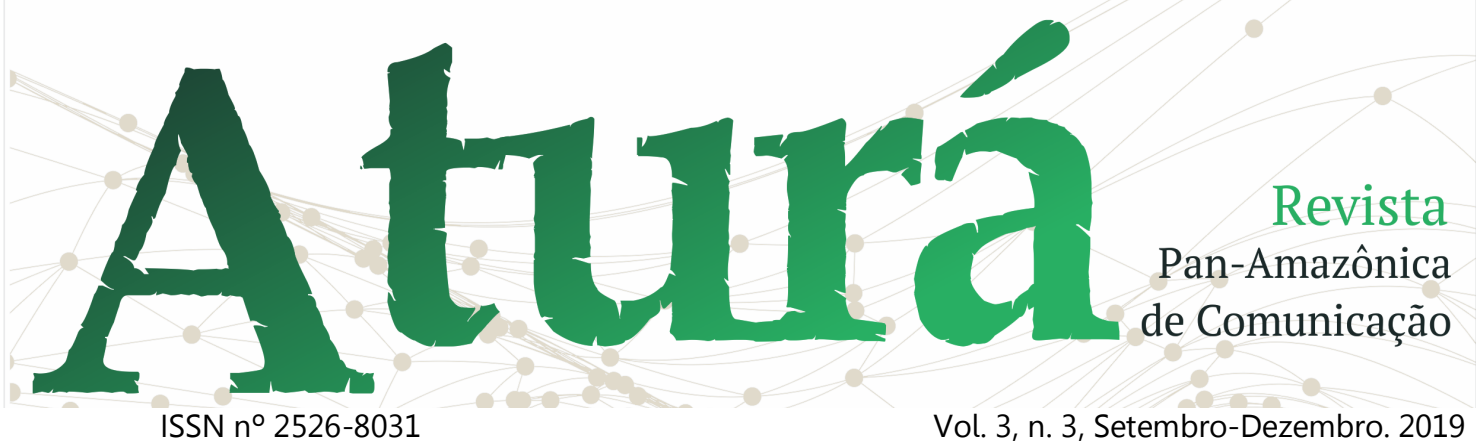

diretamente administrado pelo governo federal, pode-se sugerir as ainda parcas iniciativas vinculadas ao letramento ou mesmo ao desenvolvimento de uma rede de comunicações que integrasse Roraima ao restante do território brasileiro. É somente durante os anos de 1970, inclusive por iniciativa do regime militar, que a BR 174, principal via de integração de Roraima ao restante do Brasil, começaria a ser edificada.

No contexto do regime militar brasileiro, O Jornal Boa Vista circulou entre 1973 e 1983 como porta-voz do governo territorial de Roraima. Apresentava-se como sendo responsável por realizar a difusão da ideologia de "Desenvolvimento, Integração e Segurança" transmitida pelo Governo Federal para as populações da região. O jornal, segundo Rodrigues (1996), era uma vitrine de propaganda das ações realizadas pelo Governo Federal em Roraima, tendo como objetivo principal conectar a população às notícias relacionadas aos projetos de desenvolvimento de acordo com interesses políticos ainda orbitados em torno da administração central.

Persiste neste período o surgimento de jornais que estavam à frente de determinados grupos políticos e que, com o término de seus mandatos, deixavam de circular. Como lembra Jupira Joaquim, "os jornais eram ligados aos políticos, era comum o aparecimento deles na época de eleições, como também o seu desaparecimento quando terminava o processo eleitoral, principalmente se o dono do jornal não fosse eleito ou reeleito" (JUPIRA, 2003, p 138) 


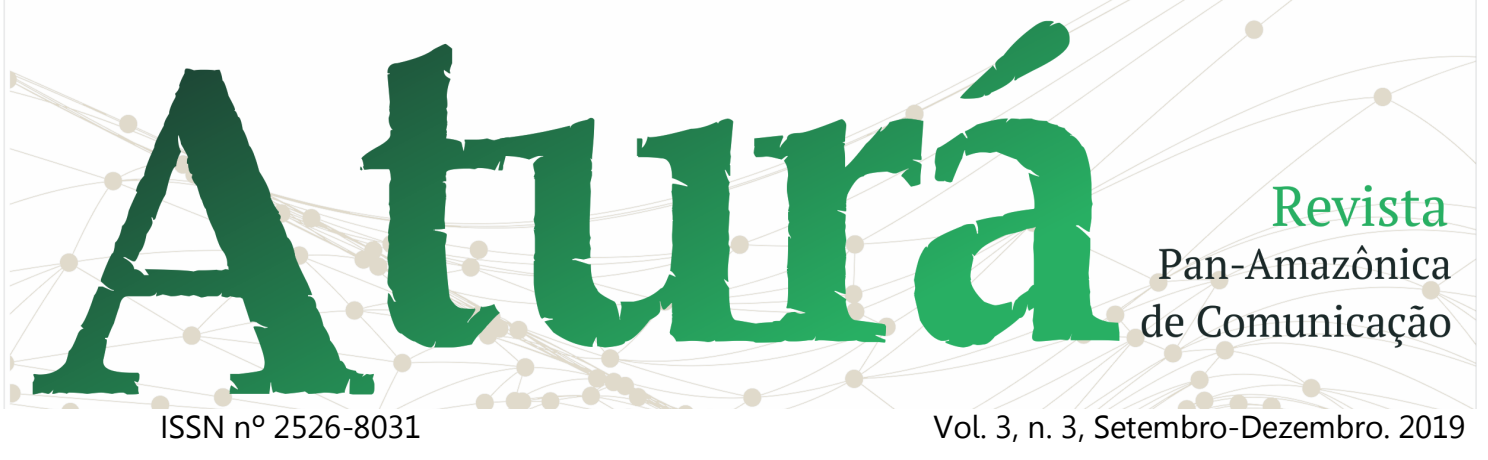

Figura 2 - Jornal Boa Vista, 1973

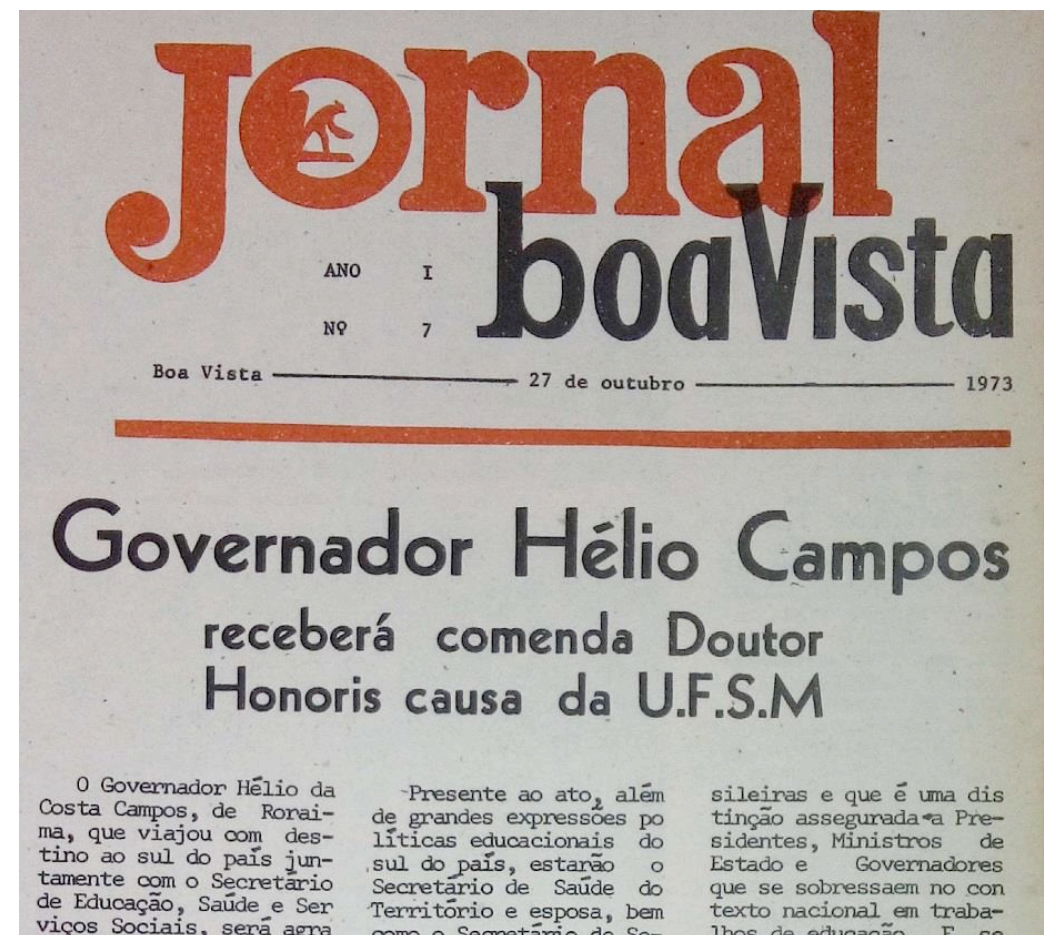

Fonte: Jornal Boa Vista, 1973, capa, Hemeroteca da Universidade Federal de Roraima

Em 1976, o jornalista Sidney Mendes trouxe sua tipografia de Rondônia para Roraima e lançou o jornal O Roraima com linha editorial sugestiva: "É batendo que se colhe". Além de possuir correspondentes nas principais cidades brasileiras, era um jornal de oposição e tinha com diretor Inácio Mendes e como gerente Maria S. Marques dos Santos. Este jornal parou de circular na $2^{a}$ edição porque a Justiça de Território Federal de Roraima alegou que o jornal era ilegal, pois não possuía licença da municipalidade nem era inscrito na junta comercial (CRUZ, 1998). Meses depois, regularizado, o jornal voltou a circular em estilo político moderado, tendo como redatores Sidney Mendes, Augusto Matheus, Selby Mendes, Nelson Orofino, Carlos Alberto e Jaber Xaud. Sidney Mendes ainda tentou continuar na carreira jornalística, lançando em 1977 o jornal Tribuna de Mucajaí, jornal que teve vida efêmera, vindo a fechar meses depois. Como lembra Menezes, havia várias situações em que os jornais foram obrigados a fechar por conta de atritos com políticos: "O Roraima fechou por perseguição 


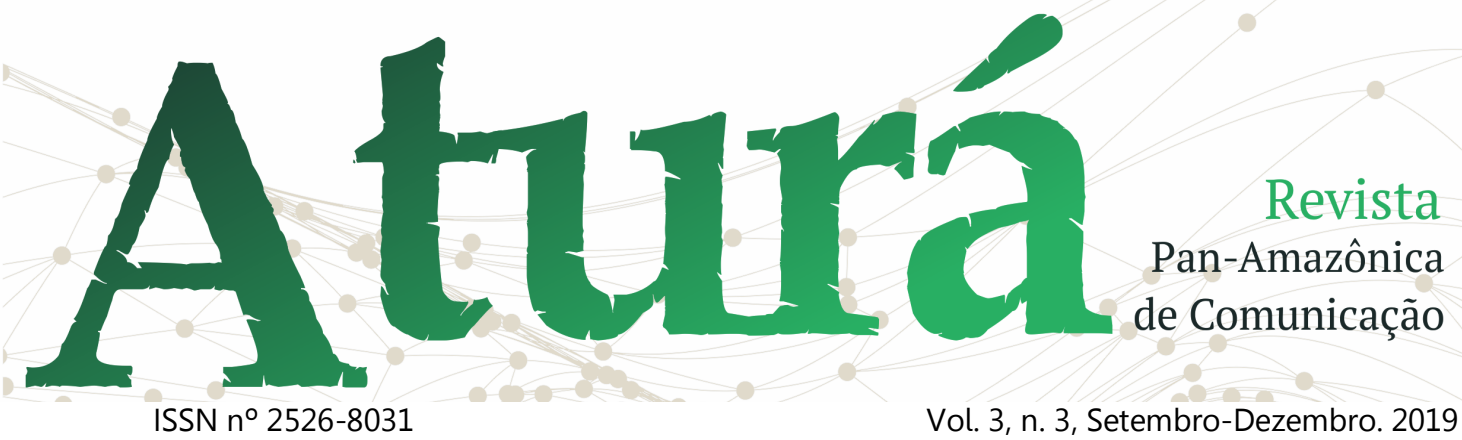

do governo Ottomar de Souza Pinto, na primeira 'nomeadura' (sic) a governo do Território. Sidney Mendes era perseguido o tempo todo. $E$ os outros que também sofreram assim... esses saiam pela tangente porque tinham um jogo de cintura, não eram radicais" (MENEZES, 2014, p. 4).

Figura 3 - Jornal O Roraima, 1982

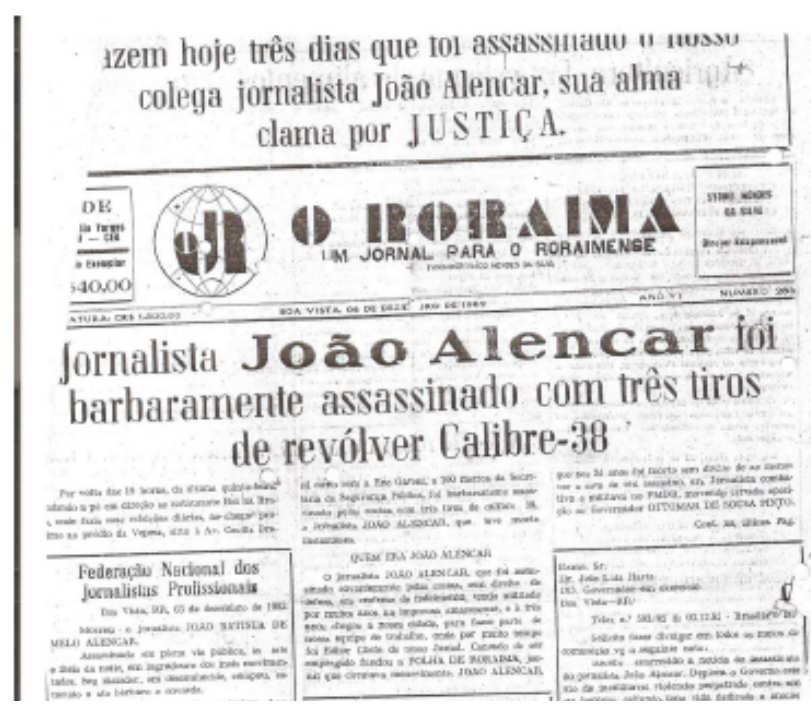

Fonte: Jornal O Roraima, 1982. p 1, Capa, 1982, Hemeroteca da UFRR

\section{A partir de 1980: fase de consolidação} do jornalismo impresso em Roraima

A década de 1980 marca o surgimento de maior variedade de jornais e iniciativas editoriais mais sólidas em Roraima, conforme se complexificava a vida social regional impulsionada pela migração vinculada sobretudo às zonas de garimpo e também conforme os ecos da redemocratização alcançavam todo o país. Em 1980, foi impresso o jornal O Observador - Sentinela da Verdade. De acordo com o relato do jornalista Laucides Oliveira, "em 1978 surgiu outro jornal, $O$ Observador, que era de propriedade do advogado Silvio Sebastiao de Castro Leite que se lançou na política em 1978. Esse jornal foi o impresso de oposição com uma maior influência política neste ano, também combatido de forma até violenta pelo ex-governador Ottomar Pinto (19791983)". Silvio Leite foi eleito prefeito de Boa Vista em 1985 e assassinado em 1987 em uma emboscada (RODRIGUES, 1986, p. 35). Disputas políticas, num contexto pósditadura, que ainda guardavam profunda herança do autoritarismo.

Em 1980 também foi criado o jornal a Folha de Roraima - um jornal a serviço de Roraima com tiragem inicial de mil exemplares. Apresentando linha editorial combativa, tinha em seu quadro de redatores Amazonas Brasil, escritor e ex-conselheiro do 


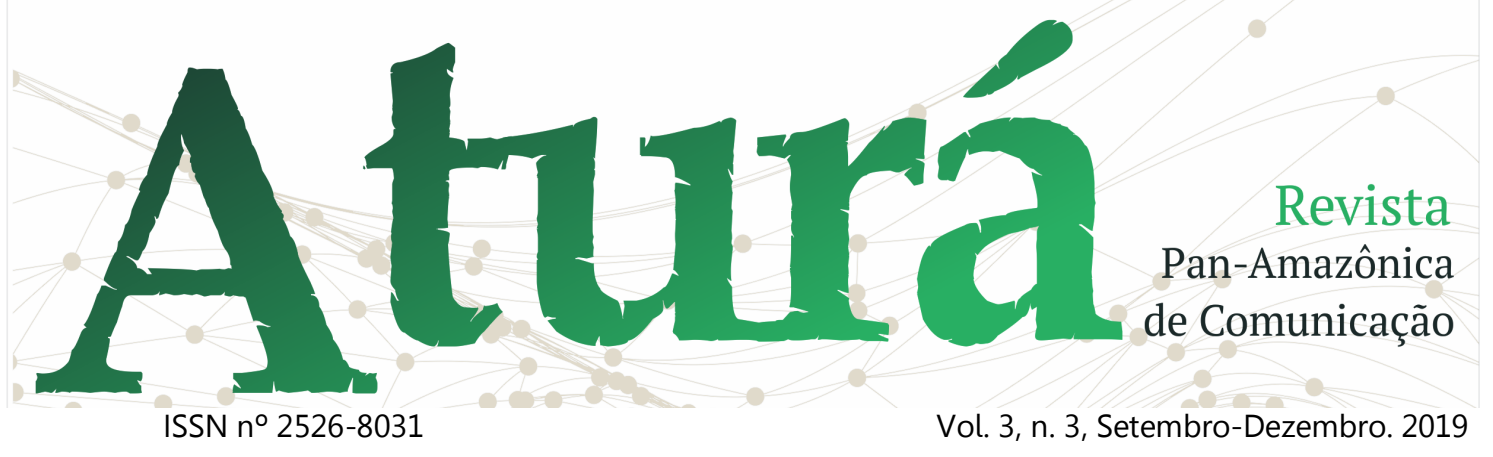

Tribunal de Contas do Estado de Roraima (TCE/RR). O jornal era vendido em uma banca de revista e esgotava rapidamente as suas edições pois, segundo relatos, pessoas ligadas ao governador compravam os exemplares em grande quantidade como forma de impedir que os demais leitores tivessem acesso ao jornal. A intenção desse jornal era fazer oposição ao governador territorial da época, o brigadeiro Ottomar Pinto. Em 1982, cessou abruptamente sua edição após o assassinato de João Batista de Melo Alencar, o jornalista proprietário e responsável pelo jornal. Conforme Cruz,

A última edição é de final de novembro de 1982 (...) Nessa edição o jornalista João Batista Melo de Alencar, com seu estilo combativo, destacava na primeira página a fotografia do rosto do Governador, com o \{ "Queremos essa cabeça fora de Roraima"\} (...) coincidentemente, Alencar foi barbaramente assassinado no dia 02 de dezembro, poucos dias depois da circulação do jornal(...) com o jornalista José de Alencar, morreu também a Folha de Roraima (1998, pp. 29-30).

Ottomar foi acusado de ser um dos dois homens que contratou os pistoleiros que assassinaram o jornalista, o que levou à sua remoção pelo então presidente João Figueiredo.

\section{Figura 4 - Jornal Folha de Roraima, 1982}

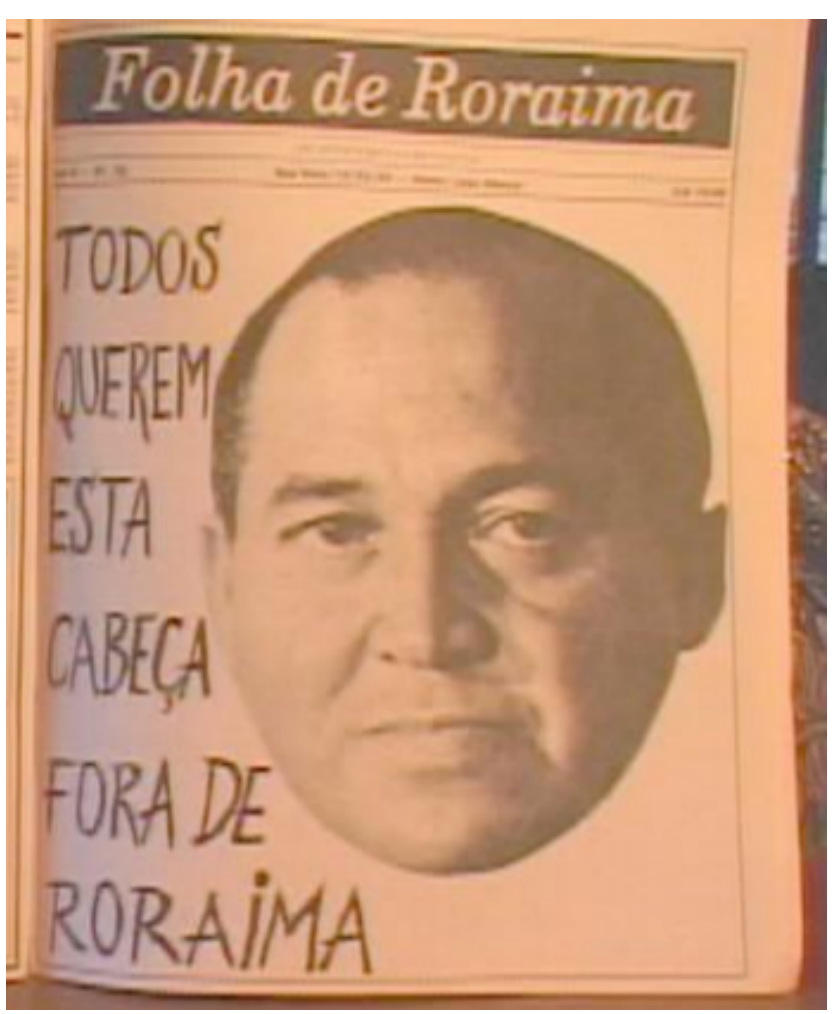

Fonte: Jornal Folha de Roraima, Capa, 1982

Outros pequenos jornais em Roraima no período de 1980 a 1990 surgiram e desapareceram rapidamente. É o caso do jornal Gazeta de Roraima ou simplesmente Gazeta Feminina de propriedade do jornalista Fernando Quintella (CRUZ, 1998). A Gazeta 


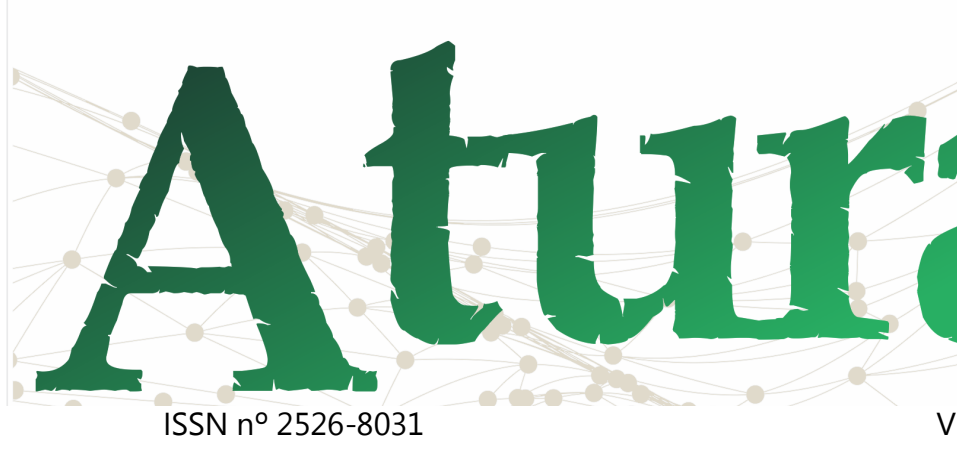

Vol. 3, n. 3, Setembro-Dezembro. 2019
Feminina destinou espaço a assuntos até então inexistentes nas páginas dos jornais locais. Trazia como novidade matérias que falavam de moda, beleza, culinária e decoração, com formato tabloide e circulação mensal. Sua linha editorial era mais analítica do que informativa. Em suas páginas publicavam-se também assuntos de cunho social e político. Um traço muito forte e constante era sentido na página de esportes, característica própria de seu criador que atuou como repórter e cronista esportivo nos jornais cariocas. Mas a Gazeta Feminina circulou apenas em duas edições: a de dezembro de 1981 e a de fevereiro de 1982. A edição de janeiro não chegou a ser impressa. Muitas foram as pressões para a mudança do perfil do jornal.

A partir daí surgiu $A$ Gazeta, impresso em cores no Amazonas. Ele se caracterizou nesse período e até outubro de 1983 por uma linha editorial voltada basicamente aos serviços. Viveu e circulou no momento de abertura política do país, experimentando as eleições diretas para presidente num contexto de possibilidade ampliada de circulação de informação. Após dois anos de circulação da primeira edição de $A$ Gazeta, o mercado editorial tomou um novo rumo com a notícia do fechamento do jornal Boa Vista de propriedade do governo do ex-território federal de Roraima (1973-1983). No dia 1 de outubro de 1983 , circulou a edição no 20 de $A$ Gazeta, a primeira da sua fase semanal. Em 1988, a conjuntura do país começava a mudar com a reforma constitucional e com a transformação de Roraima e Amapá em Estados Federados, transformando também a conjuntura política local e ampliando o espaço para as disputas partidárias pelo cargo de governador.

A Gazeta mudou de título pela segunda vez mantendo a razão social Editora Quintella Ribeiro Ltda, passando a ser chamado Gazeta de Roraima. Nesse período, o jornal ocupou um papel de destaque na imprensa de Roraima pela importância de suas realizações. Uma delas foi a conquista, em 1991, do Prêmio Esso de Jornalismo Regional Norte com a reportagem "Bandeira brasileira hasteada na fronteira", de autoria da repórter Kátia Brasil, prêmio que nenhum jornal semanário havia conquistado até então. Para a imprensa dos antigos territórios (Acre, 


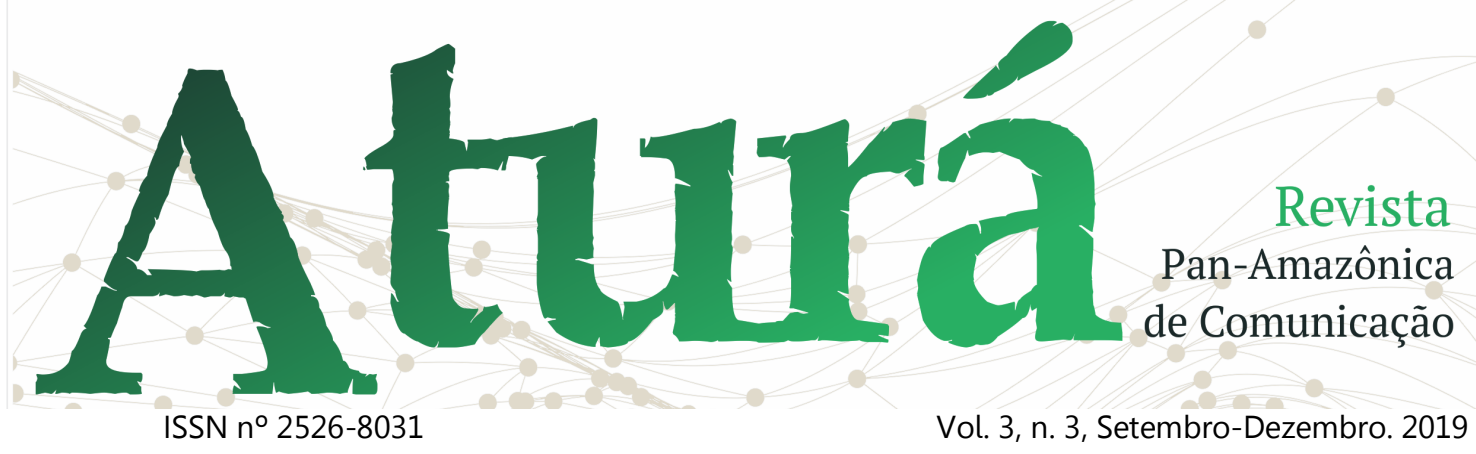

Rondônia, Amapá e Roraima) também era uma conquista inédita.

Em 1986, surgiu o semanário Tribuna de Roraima de propriedade do empresário Rubem de Lima Filho, editado pelos jornalistas Péricles Perruci, Élson Ney Rodrigues e Plínio Vicente. Este periódico em termos de noticiosos foi pouco marcante em relação aos impactos políticos dos demais jornais que existiram antes (CRUZ, 1998). Perfazendo o perfil típico de muitos jornais surgidos em Roraima, em 1987 um grupo político ligado ao deputado Olavo Pires, do Estado de Rondônia, provavelmente com pretensões políticas na região, fundou o jornal Diário do Povo (CRUZ, 1998).

Muitos outros jornais na década de 1980 surgiram e desapareceram repentinamente. Entre os mais conhecidos estão $A$ Crítica de Roraima que surgiu em 1986, após a Rede Calderaro de Comunicação do Estado do Amazonas lançar o jornal como novo projeto de comunicação em Roraima. Com circulação diária em tamanho standart 12 , com oito páginas e matérias nacionais do Estado do Amazonas e estrangeiras, o periódico ficou em circulação até novembro de 1990 (CRUZ, 1998 p. 35). Sobre este empreendimento, sugere Cruz,

\begin{abstract}
O que inviabilizou a manutenção do jornal no estado, é que Calderaro levando em conta sua potencialidade política na região e a amizade em Brasília com Antônio Carlos Magalhães, ministro da comunicação naquela época, tinha certeza que iria conseguir um canal de rádio e televisão. Quando soube que os canais tinham sido distribuídos entre os políticos locais, Calderaro em 1990, telefonou a Laucides e disse: Muito obrigado a você e ao pessoal, vamos fechar o jornal, não me interessa ficar só com um jornal aí... (CRUZ, 1998 p. 36-37).
\end{abstract}

Já no final da década, apareceu $\mathrm{O}$ Jornal - O jornal da integração BrasilVenezuela, depois que Fernando Estrela vendeu a Folha de Boa Vista. Começou a circular no dia 22 de agosto de 1988 estendido até Santa Helena do Uairém (Venezuela), onde foi montada uma sucursal. Apesar do grande sucesso, O Jornal deixou de circular em 1992, deixando atrás de si um lastro já consolidado de jornalismo impresso de fisionomia tipicamente regional.

Não de menor importância, mas cujo estudo aprofundado será guardado para um próximo artigo, dado que o jornal ainda existe e influenciou de forma fundamental os rumos 


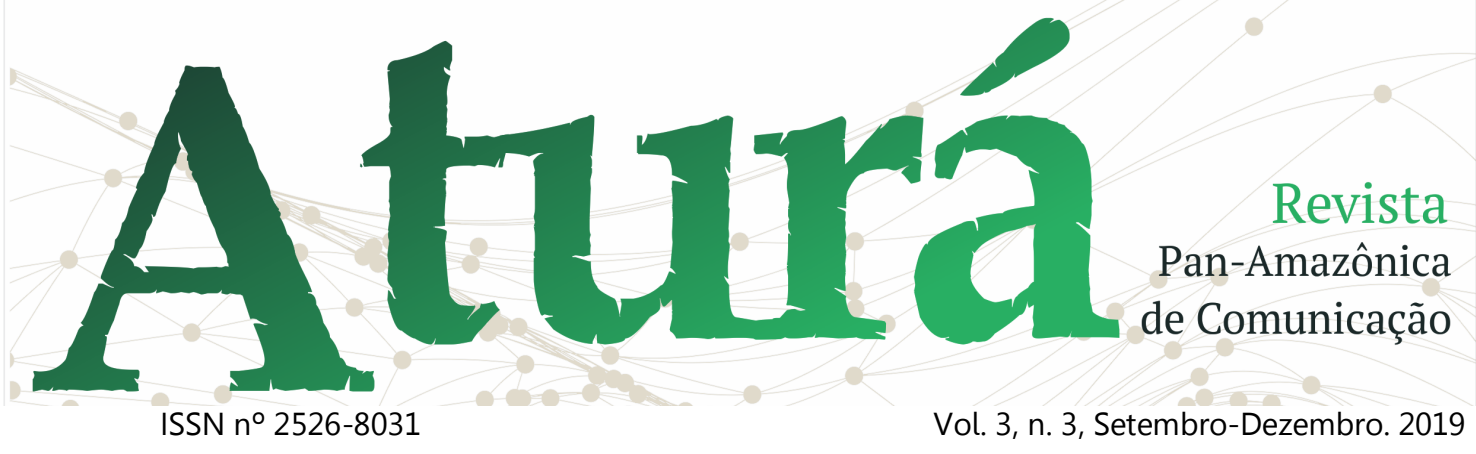

da política local, é o jornal Folha de Boa Vista. A Folha foi fundada em 21 de outubro de 1983 por inciativa de Getúlio Cruz, governador do território de Roraima entre 1985 e 1987 e prócere de intensas disputas políticas com outro indivíduo que se tornaria cacique político local e patrocinador de jornais, Romero Jucá.

\section{Considerações finais}

Este trabalho tornou bastante claro que a imprensa roraimense enfrentou constante insegurança sobre o material a ser publicado, até mesmo pelas diversas formas e manifestações da censura que ocorreram via financiamento privado e governamental, ou até mesmo autocensura dos empresários do ramo e dos próprios jornalistas que buscavam sobreviver num terreno com modestos índices de alfabetização e constantes interferências políticas do poder central.

Como herança desse processo, ainda hoje a imprensa local é marcada pelo encolhimento da circulação de jornais diários e sua estrita dependência de poderes políticos, que manifestam alguma herança da política patrimonialista dos primeiros coroneis. $\mathrm{Na}$ medida em que escreve, o jornalista fixa determinados fragmentos de memória, hierarquiza aquilo que é importante em detrimento do que deve ser esquecido e, assim, acaba sendo um ator ativo no processo de construção - político - da história. Foi nesse sentido que, como demonstrado, o jornalismo roraimense serviu de voz e expressão de determinados grupos políticos, mitigando os seus ideais de independência e imparcialidade, servindo de mediador para benefício político de grupos que disputavam a posse dos aparelhos de poder.

Este foi um esforço preliminar para compreender a imprensa em Roraima do ponto de vista diacrônico, visando entender o predomínio do clã político como filtro fundamental para a informação publicamente disponível. Oferecendo mais uma via de entrada para o estudo do tema, pretendeu-se reforçar o quanto ainda é necessário avançar na análise sobre o discurso ideológico e as estratégias de desenvolvimento nacionais relativamente ao Norte do Brasil que ainda são fundamentais para a determinação das pautas jornalísticas. 


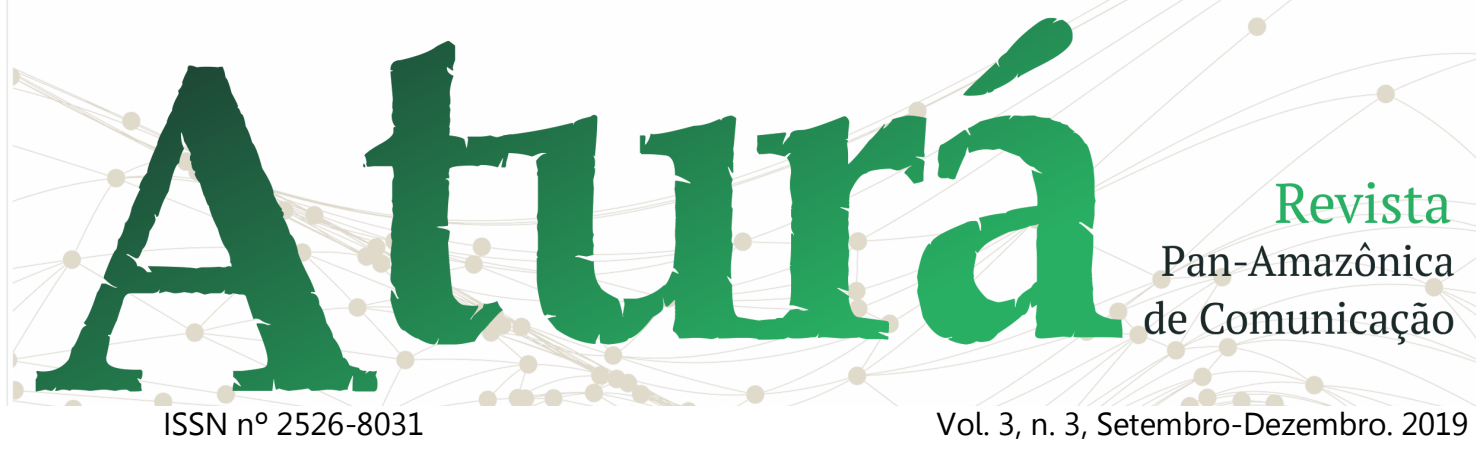

\section{Referências}

ANDRADE, Ademir José Mauro de. O jornal Boa Vista: porta-voz dos projetos desenvolvidos no território de Roraima no período de 1973 a 1979 / Ademir José Mauro de Andrade. - Boa Vista, 2016. 103 f. : il.

CARNEIRO, José Maria Gomes. IMPRENSA OFICIAL - A necessidade de notícias - um sentido social. Monografia. Centro de Comunicação, Educação, Letras e Secretariado. Departamento de Comunicação Social. Universidade Federal de Roraima. Boa Vista, 1998.

CRUZ, Jacy Souza. Jornais impressos de Roraima - 1905 - 1997. Departamento de Comunicação Social. UFRR. Boa Vista, 1998.

FERREIRA, Paulo Roberto. Mais de 180 anos de imprensa na Amazônia. Disponível em: www.jornalismo.ufsc.br/redealcar/cd3/midia/ paulorobertoferreira.doc

JUPIRA, S. S. Raposa Serra do Sol: Demarcação Territorial. Disputa Ideológica dos Atores nas Notícias da Imprensa Roraimense. 2003. 186 f. Dissertação Escola de Comunicações e Artes, Universidade de São Paulo.

LEAL, Victor Nunes Leal. Coronelismo, enxada e voto. 7a ed. São Paulo: Cia das Letras, 2012.

LIMA, Maria Goretti Leite de. O índio na imprensa em Roraima. Boa Vista: Ed: UFRR, 2008.

MENEZES, Murilo Bezerra de. (Entrevista concedida a Paulo Sérgio Rodrigues em 16/05/2006.)
MUNARO, Luís Francisco. Rios de palavras: a imprensa nas periferias da Amazônia (18211921). [recursoeletrônico] / Luís Francisco Munaro (Org.) -- Porto Alegre, RS: Editora Fi, 2017.

MUNARO, Luís Francisco. Coronéis, jornais e a formação dos municípios no Amazonas. REVISTA OBSERVATÓRIO, v. 4, p. 1, 2018.

PIMENTEL, Regina Lúcia Brito Piancó. O jornalista, o repórter e a mídia impressa em Roraima. Boa Vista/UFRR/1996. Centro de Comunicação e Letras.

REMÒND, René (Org.). Por uma História Política. $2^{a}$ ed. RJ: Editora FGV, 2003

RODRIGUES, Francilene dos Santos. "Garimpando" a sociedade roraimense: uma análise da conjuntura sócio política. Tese de Mestrado, 1996.

RODRIGUES, Shirley. A imprensa escrita em Roraima: uma questão de ética. Boa Vista: Compukromos, 1996.

SANTOS, Nelvio Paulo Dutra. Políticas Públicas, Economia e Poder. O Estado de Roraima entre 1970 e 2000. 2004, 270f Tese (Doutorado em História) - Desenvolvimento sustentável do Trópico úmido (PDTU). Núcleo de altos estudos da Amazônia, Universidade Federal do Pará, Belém, 2004.

SILVA, Paulo Sergio Rodrigues da. A violência contra os povos indígenas em Roraima: uma análise histórica a partir do Jornal Folha de Boa vista (1996 a 2005) / Paulo Sergio 


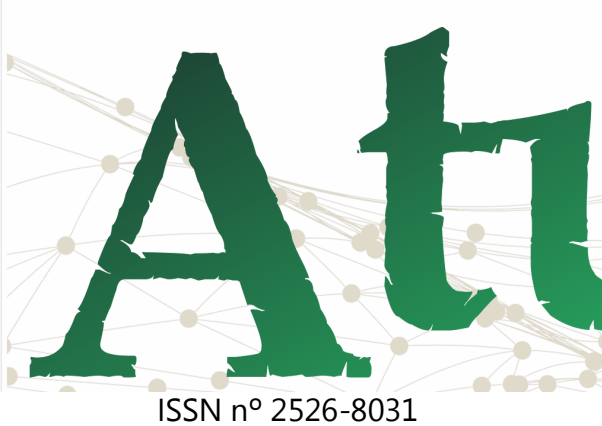

ISSN n² 2526-8031
Revista

Pan-Amazônica

de Comunicação

Vol. 3, n. 3, Setembro-Dezembro. 2019
Rodrigues da Silva. -- Boa Vista, 2014. 150 p. : il.

SANTOS, Francisco Jorge dos. Cem anos de imprensa no Amazonas: (1851-1950) : catálogo de jornais. Edição2. ed.ed. U. Calderaro), 1990.
SOARES, Jacy Souza Cruz. Jornais Impressos de Roraima - 1905-1997. Centro de Comunicação, Educação, Letras e Secretariado. Departamento de Comunicação Social. Universidade Federal de Roraima. Voa Vista, 1998. 